Louisiana State University

LSU Digital Commons

6-1-2016

\title{
Mechanisms of regulation of invasive processes in phytoplankton on the example of the north-eastern part of the Black Sea
}

\author{
V. A. Silkin \\ P.P.Shirshov Institute of Oceanology, Russian Academy of Sciences
}

A. I. Abakumov

Institute for Automation and Control Processes, Far Eastern Branch, Russian Academy of Sciences

L. A. Pautova

P.P.Shirshov Institute of Oceanology, Russian Academy of Sciences

S. V. Pakhomova

P.P.Shirshov Institute of Oceanology, Russian Academy of Sciences

A. V. Lifanchuk

P.P.Shirshov Institute of Oceanology, Russian Academy of Sciences

Follow this and additional works at: https://digitalcommons.Isu.edu/biosci_pubs

\section{Recommended Citation}

Silkin, V., Abakumov, A., Pautova, L., Pakhomova, S., \& Lifanchuk, A. (2016). Mechanisms of regulation of invasive processes in phytoplankton on the example of the north-eastern part of the Black Sea. Aquatic Ecology, 50 (2), 221-234. https://doi.org/10.1007/s10452-016-9570-7

This Article is brought to you for free and open access by the Department of Biological Sciences at LSU Digital Commons. It has been accepted for inclusion in Faculty Publications by an authorized administrator of LSU Digital Commons. For more information, please contact ir@lsu.edu. 


\title{
Mechanisms of regulation of invasive processes in phytoplankton on the example of the north-eastern part of the Black Sea
}

\author{
V. A. Silkin • A. I. Abakumov • L. A. Pautova • \\ S. V. Pakhomova $\cdot$ A. V. Lifanchuk
}

Received: 28 August 2015/ Accepted: 18 February 2016/Published online: 14 March 2016

(C) Springer Science+Business Media Dordrecht 2016

\begin{abstract}
In the north-eastern part of the Black Sea, the seasonal complexes of dominant species of phytoplankton were fixed: small-celled diatom (spring), coccolithophores (late spring, early summer) and large diatoms (summer and autumn). In May-June 2005 and 2006, two invasive species of marine diatoms Chaetoceros throndsenii (maximal abundance $1.92 \times 10^{5}$ cells/l) and Chaetoceros minimus $\left(1.6 \times 10^{5}\right.$ cells/l) were recorded. These species have been incorporated in the complex of the late spring and early summer and grew simultaneously with the coccolithophore Emiliania huxleyi. The coccolithophore was dominant species, whose abundance had reached the level of a bloom. C. throndsenii was observed over the entire area
\end{abstract}

Handling Editor: Bas Ibelings.

V. A. Silkin $(\bowtie) \cdot$ A. V. Lifanchuk

The Southern Branch of the P.P. Shirshov Institute of Oceanology RAS, Prostornaya str. 1,

Gelendzhik 353467, Krasnodar Region, Russia

e-mail: vsilkin@mail.ru

\section{A. I. Abakumov \\ Institute of Automation and Control Processes, Far Eastern Branch RAS, Vladivostok 690014, Russia e-mail: abakumov@iacp.dvo.ru}

L. A. Pautova $\cdot$ S. V. Pakhomova

P.P. Shirshov Institute of Oceanology RAS, Nakhimovski prosp. 36, Moscow 117997, Russia from the coast to the centre of the sea; $C$. minimus were recorded at coastal stations and only at two stations of the open sea. Stratification of the water mass and the low (below the Redfield) ratio of nitrogen to phosphorus were observed at this time. Then, C. throndsenii was not marked even once, and $C$. minimus has been registered once on a shelf in June 2011. Experimental studies (2005) have shown that intensive growth $C$. throndsenii requires the simultaneous addition of nitrogen and phosphorus in a ratio close to the Redfield ratio. $C$. minimus shows the intensive growth only at high concentrations of phosphorus and at low nitrogento-phosphorus ratio (the experiment was carried out in June 2011). Mathematical modelling shows that C. throndsenii and Emiliania huxleyi form a stable couple whose growth is limited by different factors: the diatoms by nitrogen and the coccolithophores by phosphorus. C. minimus might not be able to form a stable couple with coccolithophores because they have the same limiting factor, i.e. phosphorus. However, this species could become the dominant one, if low (0.5-1) nitrogen-tophosphorus ratio conditions were stable for more than 2 months. However, this scenario is improbable in natural circumstances since the existence of this complex seasonal rarely exceeds 1.5 months.

Keywords Black sea - Chaetoceros minimus . Chaetoceros throndsenii Invasive species · Nutrient . Phytoplankton $\cdot$ Emiliania huxleyi 


\section{Introduction}

Changes in the structure of marine communities are occurring continuously throughout the history of the ecosystem of the Earth. However, it is believed that the rate of these changes is increasing, and this is largely attributed to climate change (namely warming) and invasive processes (Parmesan 2006; Walther et al. 2009). Species previously observed only in subtropical and even tropical latitudes are entering the aquatic ecosystems of temperate latitudes. Invasive processes are being observed at all levels of the ecosystems from simple organisms, such as cyanobacteria (Mehnert et al. 2010), to representatives of higher trophic levels (Parmesan 2006). There are several possible scenarios in biological invasion. Alien species may join the ecosystem, displacing native species, but after a while leave, at which point the ecosystem is restored. Alien species may gain a foothold in the ecosystem, but not play a significant role in its functioning. Finally, such species may gain a foothold and completely change the structure of the food chain, replacing some or many species. The invasion and fixation of the ctenophore Mnemiopsis leidyi in the Black Sea ecosystem are an example of possible disastrous consequences (Vinogradov et al. 1992).

Predicting the appearance of new species is not possible, because there is no way of forecasting invasive processes in ecosystems. In aquatic ecosystems, invasive processes are built on competitive relationships for a limiting growth factor. The ability with which an alien species competes for limiting resources determines the nature of the invasion. For eutrophic ecosystems with a high density of phytoplankton biomass, one of the factors limiting the growth of algae is light. A comparison of the growth curve as a function of light for native and alien species allows us to understand the selective advantages of a species (Mehnert et al. 2010). There is every reason to believe that, in oligotrophic marine ecosystems, the nutrients are the main limiting resources (nitrogen, phosphorus, silicon, etc.) operating the formation of a new community structure due to invasive processes.

In May-June of 2005 and 2006, we recorded large abundance of small diatoms: Chaetoceros throndsenii (Marino, Montresor \& Zingone) Marino, Montresor \& Zingone and Chaetoceros minimus (Levander) Marino, Giuffré, Montresor et Zingone (Pautova et al. 2011; Pautova et al. 2013). These species had not previously been recorded in the phytoplankton of the Black Sea (http://phyto.bss.ibss.org.ua) and were not included in the last review of the literature on this topic (Gomez 2008).

In marine ecosystems, there are seasonal changes in the phytoplankton community. There are also longterm trends that reduce or increase the contribution of one or other of the species in the community structure. In particular, in the Black Sea the coccolithophore growth has been heightened over the last two decades (Pautova et al. 2007; Mikaelyan et al. 2011). Obviously, to become successfully fixed in the ecosystem, the invasive species should be installed in the appropriate seasonal complex or they can at least coexist with the dominant species in a given season. Why have these invasive species appeared in this ecosystem at this particular moment and with this particular seasonal complex? What are the critical characteristics defining the conditions for their attachment and dominance in the ecosystem? We attempt to answer these questions from the results of the following investigations:

(1) In field studies, the seasonal dominant species complexes and temporal and spatial distributions of invasive species in the north-eastern part of the Black Sea were identified;

(2) In experimental studies, the growth characteristics of the invasive species were studied;

(3) The conditions of the fixation and dominance of invasive species in the ecosystem were determined by using mathematical modelling.

Invasions is a complex process which should take into account the dynamics of the environment, ecophysiological properties of invasive species and multi-level set of relationships in an ecosystem. Investigation of mechanisms of invasions requires different approaches. In this article, we have attempted to find mechanisms invasions in the phytoplankton using a combination of field observations, experimental studies and mathematical modelling.

\section{Methods}

Field studies

In May-June of 2005 and 2006 during cruises of the RVs "Aquanaut" and "Ashamba", samples of the sea 
water were taken on standard transect from Blue Bay (Gelendzhik area) to the centre of the Black Sea (Figs. 1 and 2). The samples were taken using a Rozett probe-sampler with a 5-1 Niskin bathometer. The seawater was neutralised using borax-buffered $40 \%$ formalin with a final concentration in the sample of $1 \%$. The phytoplankton was concentrated by sedimentation.

\section{Experimental studies}

In 2005 and 2011, a series of laboratory experiments were carried out in Southern Branch of the Institute of Oceanology (Gelendzhik). The influences of the addition of nitrate and phosphate on the structure of the phytoplankton community were investigated. The seawater used in the experiments was taken from the surface layer $(0-50 \mathrm{~cm})$ on the shelf station (depth of $50 \mathrm{~m}$ ) on board the vessel using 5-1 plastic containers. Experiments were carried out in 500-ml Erlenmeyer flasks, and the culture medium volumes were $200 \mathrm{ml}$. The batch method of cultivation was used in all experiments. Nitrates and phosphates were added once at the beginning of each experiment in accordance with a scheme for full factorial experiments $2^{2}$ (Maksimov 1980) (Table 1). This allowed us to apply the apparatus elaborate mathematical planning of the experiments and to present the results in the form of

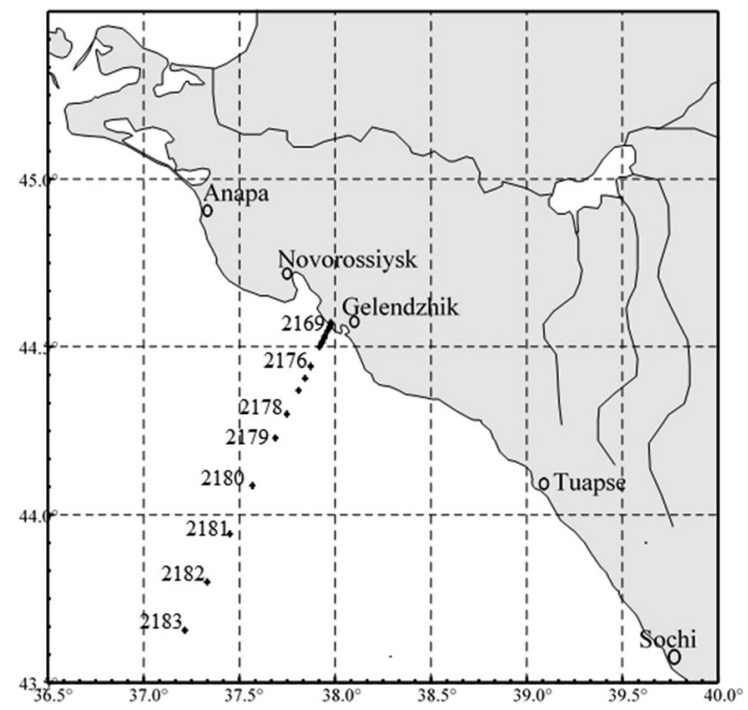

Fig. 1 Locations of stations in the 80th cruise of the "Aquanaut" 9-14 June 2005

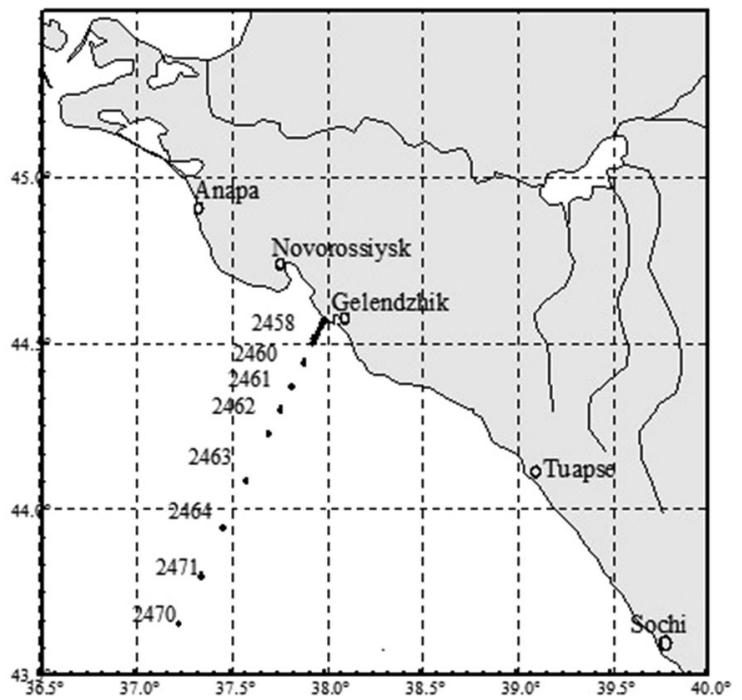

Fig. 2 Locations of stations in the 97th cruise of the "Aquanaut" 24-28 May 2006

regression equations. In Table 1, the sign of "-" indicates that the addition of the nutrient was not performed and "+" signifies that the addition was performed. To obtain the biomass of species in the stationary phase of growth, the sign - or + must be substituted for both $X_{1}$ and $X_{2}$ in the regression equation:

$Y=a_{0}+a_{1} X_{1}+a_{2} X_{2}+a_{12} X_{1} X_{2}$.

The temperature in all experiments was equal to the temperature of the seawater in nature during the period of the experiment. Incident light intensity was constant (58-61 $\mu$ mol photons $\mathrm{m}^{-2} \mathrm{~s}^{-1}$ PAR). The light:dark period ratio was 16:8.

Each variant of the experiments was carried out in two or three replicates. The Student $t$ test was used to compare different variants in the experiments, and a level of significance was set at $5 \%$.

The cells numbers counts were carried out daily (using a Nageotte chamber on $0.05 \mathrm{ml}$ ) immediately after the sampling of the culture. Algae of all systematic groups and size groups were measured, except for the picoplankton (1-2 $\mu \mathrm{m})$ fraction.

The method of geometric similarity (cells being equated to certain geometrical figures (Kiselev 1969; Hillebrand et al. 1999) was used for calculating the biomass, and biomass was estimated in terms of wet weight $\left(\mathrm{mg} / \mathrm{m}^{3}\right)$. The bloom level was taken as cell numbers greater than $1.0 \times 10^{6}$ cells $/ 1$. For 
Table 1 Plan and results of experiments to study the effect of nutrients additions on the biomass concentration of invasive species

\begin{tabular}{llllll}
\hline Variant & $\begin{array}{l}\text { Nitrogen } \\
\left(X_{1}=\mathrm{N}\right)\end{array}$ & $\begin{array}{l}\text { Phosphorus } \\
\left(X_{2}=\mathrm{P}\right)\end{array}$ & $\begin{array}{l}\text { Chaetoceros throndsenii } \\
\left(\mathrm{mg} / \mathrm{m}^{3}\right)\end{array}$ & $\begin{array}{l}\text { Chaetoceros minimus } \\
\left(\mathrm{mg} / \mathrm{m}^{3}\right)\end{array}$ & $\begin{array}{l}\text { Emiliania huxleyi } \times 10^{6} \\
(\mathrm{cell} / \mathrm{l})\end{array}$ \\
\hline 1 & - & - & 59.6 & 17.99 & 16 \\
2 & + & - & 84 & 25.41 & 12.1 \\
3 & - & + & 400 & 42.51 & 31.1 \\
4 & + & + & 210 & 21.49 & 26.3 \\
\hline
\end{tabular}

nomenclature, we used Tomas (1997), Throndsen et al. (2003), www.algaebase.org and www.marinespecies. org. Analyses for phosphate, silicate, nitrate, nitrite and ammonia were carried out using a segmented continuous-flow Technicon II autoanalyser set or by photocolourimetric methods (Bordovskiy and Chernyakova 1992; Grasshoff et al. 1999).

The structure of the model

To do identify the conditions under which a new species to the ecosystem can gain a foothold in the phytoplankton community and even become dominant, a simple model of the phytoplankton dynamics in the upper mixed layer of water (UML) was used.

There are two approaches to describe the dynamic of phytoplankton communities. The first is based on the concept of an extracellular regulation of phytoplankton growth. In this case, the specific growth rate is a function of the extracellular nutrient concentration and is described by Monod model:

$\tilde{\mu_{i j}}=\frac{\tilde{\mu}_{i j}^{m} C_{j}}{\tilde{K}_{i j}+C_{j}}$

where $\tilde{\mu_{i j}}$ and $\tilde{\mu}_{i j}^{m}$ are the current and maximal specific growth rates of $i$ th species on $j$ th nutrient, respectively; $C_{j}$ is the current concentration of $j$ th nutrient; $\tilde{K}_{i j}$ is the half-saturation constant of $i$ th species for $j$ th nutrient.

For non-stationary processes, in particular in the case of the successional processes in a phytoplankton community, we must take into account the effect of the accumulation of nutrients in the cells. This allows use a concept of intracellular regulation in which the specific growth rate depends on the intracellular nutrient content and it is expressed by the model (Droop 1974): $\mu_{i j}=\mu_{i j}^{m}\left(1-\frac{q_{i j}}{Q_{i j}}\right)$

where $\mu_{i j}$ and $\mu_{i j}^{m}$ are the current and maximal specific growth rates of $i$ th species on $j$ th nutrient, respectively; $Q_{i j}$ and $q_{i j}$ are the current nutrient content and minimal cell quota, respectively, for $j$ th nutrient in biomass of $i$ th species.

The process of nutrient uptake depends on the nutrient concentration in the environment and is usually expressed by the Michaelis-Menten function:

$v_{i j}\left(C_{i j}\right)=\frac{v_{i j}^{m}\left(C_{j}\right) C_{j}}{K_{i j}+C_{j}}$

where $v_{i j}$ and $v_{i j}^{m}$ are the current and maximal specific rate uptake, respectively, of $j$ th nutrient by $i$ th species; $K_{i j}$ is the half-saturation constant of $i$ th species for $j$ th nutrient.

The model describes the dynamics of the phytoplankton community in the upper mixed layer (UML) in the presence of the seasonal thermocline. In this case, the UML is a relatively isolated system. Vertical exchange determines the production process; that is, through the thermocline, nutrients come from the lower layers and the phytoplankton cells sink.

It is assumed that the specific cell growth rate is determined by the concentration of the limiting nutrient content. The system of equations describing the dynamics of the biomass (or cell numbers), the nutrient concentration and the nutrient content in biomass had the form:

$$
\begin{aligned}
& \frac{\mathrm{d} W_{i}}{\mathrm{~d} t}=\left[\min \mu_{i j}\left(Q_{i j}\right)-D\right] W_{i} \\
& \frac{\mathrm{d} C_{j}}{\mathrm{~d} t}=D\left(C_{o j}-C_{j}\right)-\sum_{i=1}^{n} v_{i j}\left(C_{j}\right) W_{i}
\end{aligned}
$$


$\frac{\mathrm{d} Q_{i j}}{\mathrm{~d} t}=v_{i j}\left(C_{j}\right)-Q_{i j} \min \mu_{i j}\left(Q_{i j}\right)$

where $W_{i}$ and $C_{j}$ represent the biomass concentration of the $i$ th species and the concentration of $j$ th nutrient, respectively; $C_{o j}$ is the concentration of the $j$ th nutrient in the thermocline; $D$ is the rate of water exchange in the UML.

To parameterise the model, the results of experiments with the batch and continuous culture obtained from 2005 to 2011 were used (Table 5). First of all, coefficients of the model Monod were estimated in the batch culture. Then, the rest of the model parameters were assessed. At the same time take into account the following patterns and relations (Silkin and Khailov 1988):

$\tilde{K}_{i j}=q_{i j} \cdot \frac{\tilde{\mu}_{i j}^{m}}{v_{i j}^{m}} \cdot K_{i j}$

$\tilde{\mu}_{i j}^{m}=\frac{v_{i j}^{m} \cdot \mu_{i j}^{m}}{\mu_{i j}^{m} \cdot q_{i j}+v_{i j}^{m}}$.

Taken into account that half-saturation constant and maximal growth rate in Monod equation have a positive link and such parameters of Droop equation as minimal cell quota and maximal growth rate have a similar relationship:

$\mu_{i j}^{m}=\mathrm{a}_{i j} \cdot q_{i j}$

where $\mathrm{a}_{i j}$ is the constants.

\section{Results}

Field studies

\section{Seasonal species complexes}

Long-term field studies allowed to distinguish species constantly present in the dominant complexes of the species (Table 2). The dominant species were represented by two taxonomic groups: namely diatoms and coccolithophores (E. huxleyi). Only once (in spring 2008) the dinoflagellate Scrippsiella trochoidea was included in the dominant complex of the species.

The data accumulated over the past decade allowed to identify some common patterns in the dominant phytoplankton species complex: small diatoms in spring; coccolithophores in late spring, early summer; and large cellular diatoms in summer, autumn and early winter. The spring bloom consisted of small cell diatoms Pseudo-nitzschia pseudodelicatissima and Chaetoceros curvisetus. Coccolithophores mainly dominated in the late spring and early summer in all years except 2007 and 2008. Two large cellular diatoms Proboscia alata and Pseudosolenia calcaravis were dominated in summer and autumn. The invasive species $C$. throndsenii and $C$. minimus were registered in the ecosystem in May-June, i.e. during the period when the coccolithophore was dominated.

\section{Distribution of Chaetoceros throndsenii and Chaetoceros minimus}

The small cellular centric diatom (size 3-5 $\times 7$, volume-50 $\mu^{3}$ ) C. throndsenii (Marino, Montresor \& Zingone) Marino, Montresor \& Zingone was first registered on 23 May 2005 offshore near Blue Bay (Gelendzhik) at the shelf station, and the maximum cell number of this species was recorded in surface water at $4.1 \times 10^{4}$ cells $/ 1$. In the 80 th cruise of the RV "Aquanaut" (9-14.06.2005) in the open sea, the growth of this species was more intensive $\left(1.92 \times 10^{5}\right.$ cells/l) $($ Fig. 1 ; Table 3$)$. C. throndsenii was observed simultaneously with the coccolithophore E. huxleyi, of which abundance at some stations exceeded the bloom level (Table 3).

The abundance of this invasive species ranged from $5.6 \times 10^{3}$ cells $/ 1$ (station 2183 ) to $1.92 \times 10^{5}$ cells $/ 1$ (station 2170). Thus, the maximum values were observed at stations on the shelf (stations 2168-2172), while the largest coccolithophores abundance was recorded at stations on the slope (2173 and 2174) and the open sea stations (2180 and 2181).

Another species of invader-small cellular centric diatom (size $4 \times 10$, volume-130 $\left.\mu^{3}{ }^{3}\right)$ C. minimus (Levander) Marino, Giuffré, Montresor et Zingonewas first discovered in May 2005 in the offshore waters. At the shelf station, the abundance was $1.6 \times 10^{5}$ cells $/ 1$. In the 97 th cruise of the RV "Aquanaut" (24-28 May 2006), an intensive growth of these diatoms (up to $4.4 \times 10^{5}$ cells/l) was recorded at two stations (Fig. 2, Table 4). This species was registered in the upper 20-m water layer (the upper mixed layer and the layer of the seasonal thermocline). 
Table 2 Complexes of dominant phytoplankton species in different seasons

\begin{tabular}{|c|c|c|}
\hline Season & Species & Time \\
\hline \multirow[t]{4}{*}{ Spring } & $\begin{array}{l}\text { Pseudo-nitzschia } \\
\quad \text { pseudodelicatissima }\end{array}$ & Mach to April 2007 \\
\hline & Chaetoceros curvisetus & April 2008 \\
\hline & Emiliania huxleyi & April 2009; April 2011 \\
\hline & Scrippsiella trochoidea & March to April 2008 \\
\hline \multirow[t]{5}{*}{ Late spring, early summer } & Emiliania huxleyi & May, June 2004, 2005, 2006, 2009, 2010, 2011, 2012, 2013 \\
\hline & Chaetoceros curvisetus & May-June 2007 \\
\hline & Proboscia alata & June 2009; May-June 2010 \\
\hline & $\begin{array}{l}\text { Pseudo-nitzschia } \\
\quad \text { pseudodelicatissima }\end{array}$ & June 2009; May 2010 \\
\hline & Pseudosolenia calcar-avis & May 2008; June 2010 \\
\hline \multirow[t]{4}{*}{ Summer } & $\begin{array}{l}\text { Pseudo-nitzschia } \\
\quad \text { pseudodelicatissima }\end{array}$ & August 2002; September 2003; August 2006 \\
\hline & Proboscia alata & July 2007; July-August 2008; July 2009 \\
\hline & Pseudosolenia calcar-avis & July 2007; early 2008; July to early September 2012 \\
\hline & Emiliania huxleyi & July 2006; July to September 2012 \\
\hline \multirow[t]{3}{*}{ Autumn } & Proboscia alata & October 2007; November 2008; October 2009; October 2010 \\
\hline & Pseudosolenia calcar-avis & September-October 2006; September 2007, 2008; October 2012 \\
\hline & Emiliania huxleyi & November 2006; October 2012 \\
\hline \multirow[t]{3}{*}{ Winter } & Proboscia alata & December 2009 \\
\hline & Emiliania huxleyi & December 2006, 2009, 2010 and 2012 \\
\hline & Pseudosolenia calcar-avis & December 2012 \\
\hline
\end{tabular}

Table 3 Abundance and biomass of coccolithophores Emiliania huxleyi and Chaetoceros throndsenii at stations $9-14$ June 2005 (80th cruise RV "Aquanaut")

\begin{tabular}{lcllll}
\hline Station & \multicolumn{2}{l}{ Chaetoceros throndsenii } & & \multicolumn{2}{l}{ Emiliania huxleyi } \\
\cline { 2 - 3 } & Abundance (cells/l) & Biomass $\left(\mathrm{mg} / \mathrm{m}^{3}\right)$ & & Abundance (cells/l) & Biomass $\left(\mathrm{mg} / \mathrm{m}^{3}\right)$ \\
\hline 2168 & 144,000 & 7.2 & 399,600 & 71.9 \\
2169 & 140,000 & 7 & 263,200 & 47.4 \\
2170 & 192,000 & 9.6 & 984,000 & 177 \\
2171 & 8000 & 0.4 & $1,000,000$ & 183 \\
2172 & 168,000 & 8.4 & 944,530 & 170 \\
2173 & 6400 & 0.32 & $1,248,000$ & 224.6 \\
2174 & 12,800 & 0.64 & $1,190,400$ & 214.2 \\
2175 & 32,000 & 1.6 & 627,200 & 112.9 \\
2176 & 16,000 & 0.8 & 299,000 & 53.8 \\
2177 & 29,000 & 1.44 & 691,200 & 124.4 \\
2178 & 60,000 & 3 & 592,000 & 106.6 \\
2179 & 19,200 & 0.96 & 586,670 & 105 \\
2180 & 45,000 & 2.24 & $1,344,000$ & 241.9 \\
2181 & 58,000 & 2.88 & $1,622,400$ & 292 \\
2182 & 19,200 & 0.96 & 554,670 & 99.8 \\
2183 & 5600 & 0.28 & 668,270 & 119 \\
\hline
\end{tabular}


Physical conditions of growth of invasive species

The growth of invasive species was registered from mid-May to mid-June, when the depths of the mixed layer varied from 4 to $15 \mathrm{~m}$ and it was mainly in the range $8-12 \mathrm{~m}$. The surface water temperatures changed from 18 to $23.8{ }^{\circ} \mathrm{C}$, salinity from 16.75 to 17.25. The light fluxes were maximal of all values of the year.

Hydrochemical growth conditions of invasive species

Both of the invasive species $C$. minimus and $C$. throndsenii were found at high concentrations of phosphorus (0.26 and $0.44 \mu \mathrm{M}$, respectively) and silicon (9.3 and $7.6 \mu \mathrm{M}$, respectively) (Fig. 3a-c). Growth of $C$. throndsenii occurred at very low concentrations of dissolved inorganic nitrogen (DIN, $0.37 \mu \mathrm{M})$. These invasive species have been recorded in the ecosystem at the conditions of coccolithophores dominance-at N:P ratios below the Redfield ratio (7 and 1 for $C$. minimus and $C$. throndsenii, respectively) and at $\mathrm{Si}: \mathrm{N}$ ratios above the Redfield ratio (5 and 21, respectively) (Fig. 3d-f).

\section{Experimental studies}

In an experiment with natural phytoplankton populations undertaken 23 May 2005 was established that the maximum biomass of $C$. throndsenii $\left(W_{\mathrm{st}}\right)$ in batch culture depends on the initial concentration of nitrogen and phosphorus. This parameter varied from $59.6 \mathrm{mg} / \mathrm{m}^{3}$

Table 4 Abundance of coccolithophores Emiliania huxleyi and invasive species Chaetoceros minimus on the surface of the water in the sea 24-28 May 2006 (97th cruise of the RV "Aquanaut")

\begin{tabular}{lcc}
\hline Station & $\begin{array}{l}\text { Chaetoceros } \\
\text { minimus }(\text { cells/l) }\end{array}$ & $\begin{array}{l}\text { Emiliania } \\
\text { huxleyi }(\text { cells/l) }\end{array}$ \\
\hline 2458 & 0 & 864,000 \\
2460 & 0 & $1,152,000$ \\
2461 & 320,000 & $1,024,000$ \\
2462 & 0 & 269,000 \\
2463 & 0 & $2,260,000$ \\
2464 & 0 & 936,000 \\
2470 & 448,000 & $3,136,000$ \\
2471 & 0 & $4,416,000$ \\
\hline
\end{tabular}

(variant 1 without additions) to $210 \mathrm{mg} / \mathrm{m}^{3}$ (variant 4 with the simultaneous additions of nitrogen and phosphorus) (Table 1). The regression equation reproducing the influence of the additions of nitrogen and phosphorus on biomass concentration in stationary phase of batch culture $\left(W_{\mathrm{st}}\right)$ has the form (confidence interval in parentheses):

$$
\begin{aligned}
W_{\mathrm{st}}\left(\mathrm{mg} / \mathrm{m}^{3}\right)= & 114.4+32.6 X_{1}+42.6 X_{2} \\
& +20.4 X_{1} \times X_{2}(11.6),
\end{aligned}
$$

where $X_{1}$ and $X_{2}$ refer, respectively, to nitrogen and phosphorus additions.

This equation implies that only the simultaneous addition of nitrogen and phosphorus increases abundance of this species in the sea.

Another species of invader, C. minimus, first found in May 2006 but experimental studies with this species have not been carried out. This species was not fixed in the phytoplankton in the north-eastern part of the sea until the second half of June 2011 on the shelf station located over the $50 \mathrm{~m}$ depth. An experiment carried out on 24 June 2011, and it indicated that the maximum accumulated biomass of this species was in the range of $17.99-42.51 \mathrm{mg} / \mathrm{m}^{3}$ (Table 1). The highest level of biomass was observed in variant three where only phosphorus was added. The regression equation representing the influence of additions of nitrogen and phosphorus on the biomass concentration $\left(W_{\mathrm{st}}\right)$ of this invasive species has the form (confidence interval in parentheses):

$$
\begin{aligned}
W_{\mathrm{st}}\left(\mathrm{mg} / \mathrm{m}^{3}\right)= & 26.85-3.4 X_{1}+5.15 X_{2}-7.11 X_{1} \\
& \times X_{2}(3.42) .
\end{aligned}
$$

From this equation and Table 1 , it is followed that the maximum effect would be achieved with the addition of phosphorus only. The simultaneous addition of nitrogen and phosphorus would not lead to an increase in the proportion of this species in the community.

Experiments with the addition of nitrogen and phosphorus undertaken on board the RV "Aquanaut" on 26 May 2006 indicated that cell numbers of $E$. huxleyi $\left(Z_{\mathrm{st}}\right)$ depend on the phosphorus concentration (confidence interval in parentheses):

$$
\begin{aligned}
Z_{\mathrm{st}}\left(\times 10^{6} \mathrm{cell} / \mathrm{l}\right)= & 21.15-1.95 X_{1} \\
& +7.55 X_{2}-0.45 X_{1} \times X_{2}(2.25) .
\end{aligned}
$$

These experimental results allowed to estimate the kinetic parameters for the model below (Table 5). 

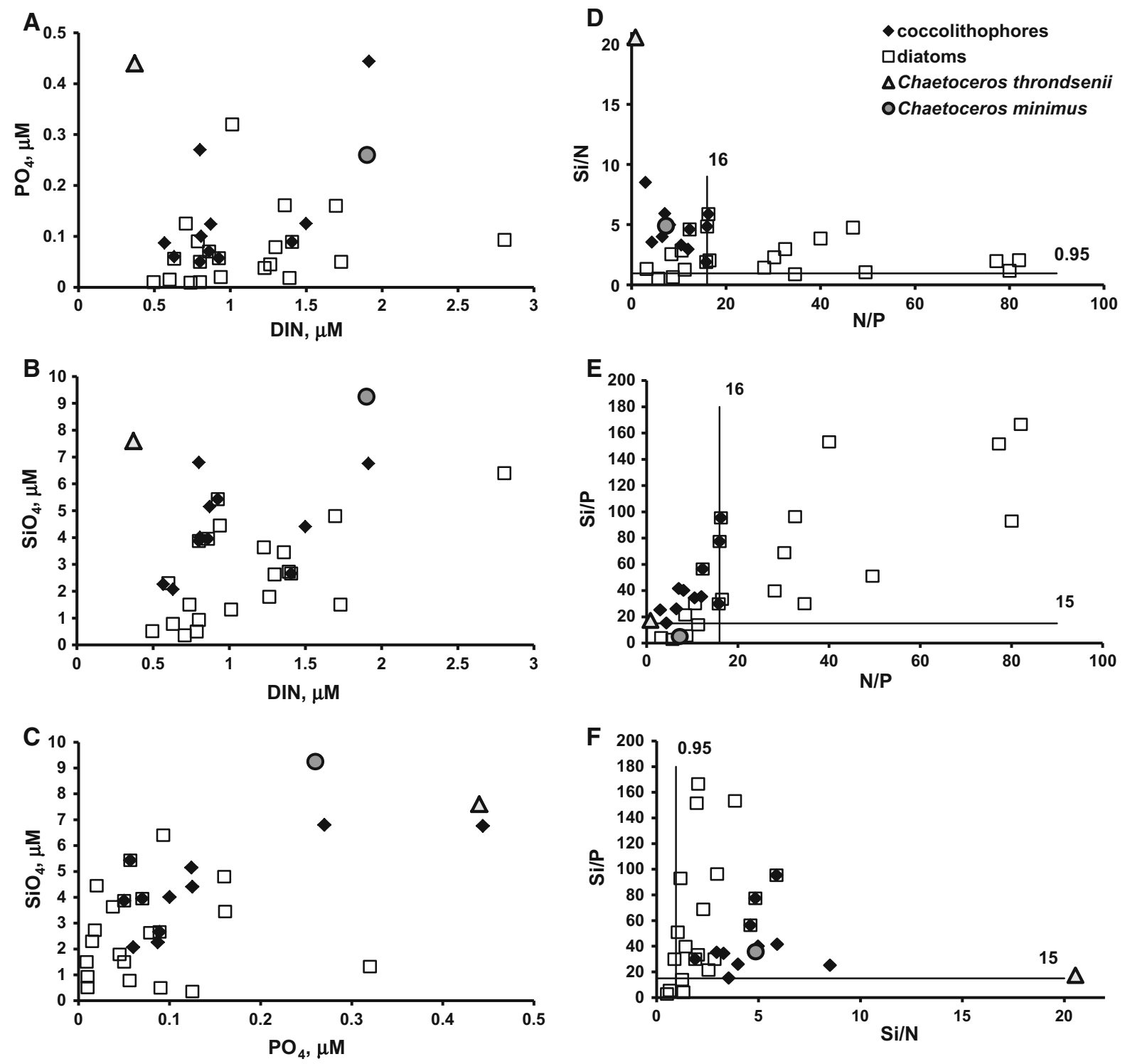

Fig. 3 Hydrochemical conditions in the upper mixed layer in the period 2002-2010 at which the dominance of coccolithophores and/or diatoms was observed and the invasive

Mathematical modelling of the dynamics of invasive species

Computational calculations were carried out for determining the conditions for fixing invasive species in the ecosystem. As native species, the diatom Pseudo-nitzschia pseudodelicatissima and the coccolithophore E. huxleyi were investigated. These species

species were detected in 2005 and 2006. Straight lines represent the Redfield values of nutrients ratios (according to Brzezinski 1985)

dominate during approximately the same time interval and can realistically compete for nutrients.

The results of the calculations showed that the phytoplankton community is sensitive to changes in the flow rate. The community is stable when the water exchange rate is less than 0.1 day $^{-1}$. Therefore, for the computational experiments this rate of water exchange was used. 
Table 5 Kinetic parameters for invasive and native species

\begin{tabular}{llllll}
\hline Parameters & Dimension & $\begin{array}{l}\text { Emiliania } \\
\text { huxleyi }\end{array}$ & $\begin{array}{l}\text { Pseudo-nitzschia } \\
\text { pseudodelicatissima }\end{array}$ & $\begin{array}{l}\text { Chaetoceros } \\
\text { throndsenii }\end{array}$ \\
\hline$\mu_{\max } \mathrm{NO}_{3}$ & $1 /$ day & 1.92 & 2.70 & 1.80 & $\begin{array}{l}\text { Chaetoceros } \\
\text { minimus }\end{array}$ \\
$\mu_{\max } \mathrm{PO}_{4}$ & $1 /$ day & 1.55 & 1.84 & 1.55 & 2.25 \\
$v^{m} \mathrm{NO}_{3}$ & $\mu \mathrm{M} /($ day $\mathrm{mg})$ & 0.0379 & 0.0771 & 0.0714 & 0.0714 \\
$v^{m} \mathrm{PO}_{4}$ & $\mu \mathrm{M} /($ day $\mathrm{mg})$ & 0.1452 & 0.5806 & 0.1161 & 0.0645 \\
$\mathrm{~K} \mathrm{NO}_{3}$ & $\mu \mathrm{M}$ & 0.1000 & 0.7143 & 0.1429 & 0.0714 \\
$\mathrm{~K} \mathrm{PO}_{4}$ & $\mu \mathrm{M}$ & 1.1613 & 0.5161 & 0.6452 & 0.2143 \\
$q_{N}$ & $\mu \mathrm{M} / \mathrm{mg}$ & 0.2143 & 0.2143 & 0.00645 & 0.2143 \\
$q_{P}$ & $\mu \mathrm{M} / \mathrm{mg}$ & 0.00645 & 0.00645 & 0.00710 \\
\hline
\end{tabular}

Fig. 4 Biomass concentration $\left(\mathrm{g} / \mathrm{m}^{3}\right)$ dynamics of native species of Pseudo-nitzschia pseudelicatissima and Emiliania huxleyi and invasive species Chaetoceros throndsenii and Chaetoceros minimus at nitrogen concentration $0.43 \mu \mathrm{M}$ and different nitrogen-to-phosphorus ratios
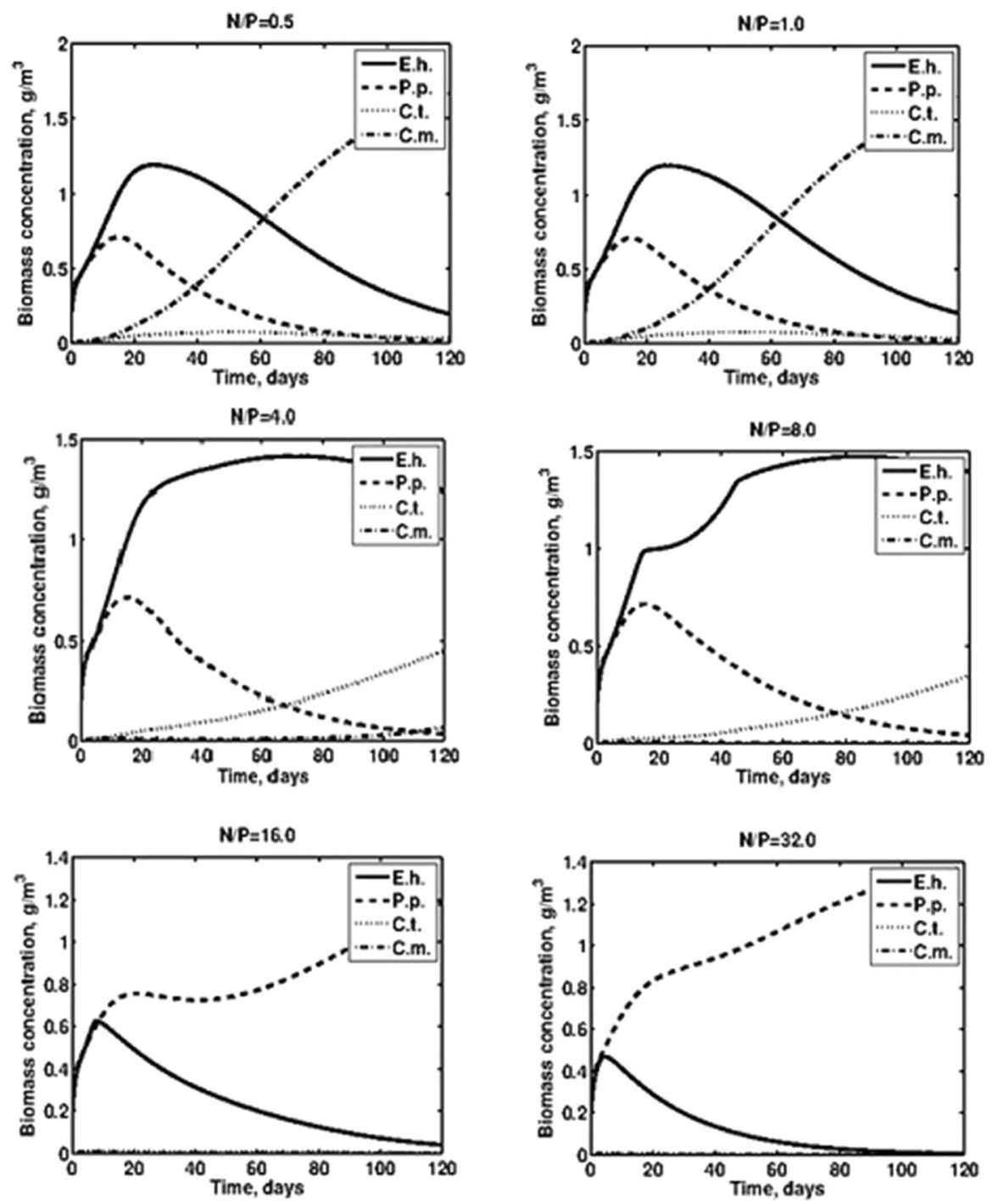
Calculations of the biomass dynamics of the native species Pseudo-nitzschia pseudodelicatissima and E. huxleyi and the invasive species $C$. throndsenii and $C$. minimus at a nitrogen concentration of $0.43 \mu \mathrm{M}$, and a range of $\mathrm{N}: \mathrm{P}$ ratios $(0.5-32)$ indicated that there are conditions for fixing these invasive species in the ecosystem (Fig. 4). When N:P ratio was 16 and above, there only were native species in the ecosystem: the diatom P. pseudodelicatissima and E. huxleyi. Eventually, the diatom displaces $E$. huxleyi, and it remains the only dominant. The invasive species did not have a chance to gain a foothold in the ecosystem. When N:P ratio was 8 and 4, E. huxleyi became the dominant species and $C$. throndsenii became an accompanying species; its share in the community can grow. When $\mathrm{N}: \mathrm{P}$ ratio was equal to $1, E$. huxleyi was the dominant species at first, and then after a 70-day period, $C$. minimus became dominant species. The other invasive species, C. throndsenii, did not have opportunity to achieve substantial growth. When $\mathrm{N}: \mathrm{P}$ ratio was 0.5 , there was a similar picture; only $C$. minimus became the dominant species at first.

By reducing the concentration of nitrogen in inflow water by half, the biomass of all species decreased, but the overall picture of the biomass dynamic did not changed significantly (Fig. 5). When N:P ratio equalled 4 or higher, the native species formed a community in which invasive species were unable to become dominant for any time. When the N:P ratio was $4, C$. throndsenii became subdominant and the native species E. huxleyi was dominant. When N:P ratio equalled 0.5 and 1 , a competition between the two species (E. huxleyi and C. minimus) increased, but with the time the invasive species became dominant. The low values of N:P ratio were observed only in 2005 and 2006 (Fig. 6). Further, only the high values of this ratio were recorded.

\section{Discussion}

Promotion of new species in the northern regions due to climate change could be the first explanation of the appearance of new species. Indeed, there are many examples of promotion of marine species at $1000 \mathrm{~km}$ north (Parmesan 2006). The newly discovered species C. throndsenii and C. minimus had been found earlier in the Mediterranean Sea (Marino et al. 1991; Genitsaris et al. 2011). Therefore, it would be attractive to consider this invasive process as a consequence of climate change. However, in subsequent years these species were not detected in the north-eastern part of the Black Sea. The temperature at which the invasive species were recorded does not differ significantly from the temperatures of the previous and subsequent years. This indicates that the temperature is not critical and that there are other mechanisms of regulation of invasive processes.

Simple scheme of succession of phytoplankton in the north-eastern part of the Black Sea was implemented: small diatoms, followed by coccolithophores, followed in turn by large diatoms, as highlighted earlier (Silkin et al. 2013). Invasive species are integrated into the ecosystem in a period when coccolithophores dominated. Therefore, these species and coccolithophores have similar conditions of existence. During this period, the maximum light intensity on the sea surface is a typical, and so it is difficult to assume that this factor was the main regulator of the community structure. Given that, the eutrophication of the north eastern part of the sea is not significant it is natural to assume that the main regulator of the community structure is the nutrients concentration.

Specific spatial distribution of invasive species $C$. throndsenii and $C$. minimus indicates the important role of nutrients concentrations. The first species was found at all stations of the standard transect and coexisted with E. huxleyi (Table 3). Its share in this two-species community was small. The maximum contribution (10 and $14 \%$ ) by $C$. throndsenii was found in the coastal stations (2168 and 2169). The role of this species was reduced on average to about $1 \%$ on the stations near the centre of the Black Sea. The other species, C. minimus, was observed only on the shelf stations in 2005, 2006 and 2011 and only on two stations of open sea in 2006 (Table 4). Small contribution of these invasive species in the total biomass of the community indicates that the nutrients concentration is insufficient for the intensive growth of phytoplankton species. In addition, these species showed higher contribution to the total biomass on a shelf where the nutrients concentration is higher.

The experiments allowed to understand the reasons for such a distribution of this invasive species. $C$. minimus is very sensitive to phosphorus concentration and shows fast growth at high concentrations of this nutrient. One would expect this species to have intensive growth in areas of elevated concentrations 
Fig. 5 Biomass concentration $\left(\mathrm{g} / \mathrm{m}^{3}\right)$ dynamics of native species of Pseudo-nitzschia pseudelicatissima and Emiliania huxleyi and invasive species Chaetoceros throndsenii and Chaetoceros minimus at nitrogen concentration $0.215 \mu \mathrm{M}$ and different ratios of nitrogen to phosphorus
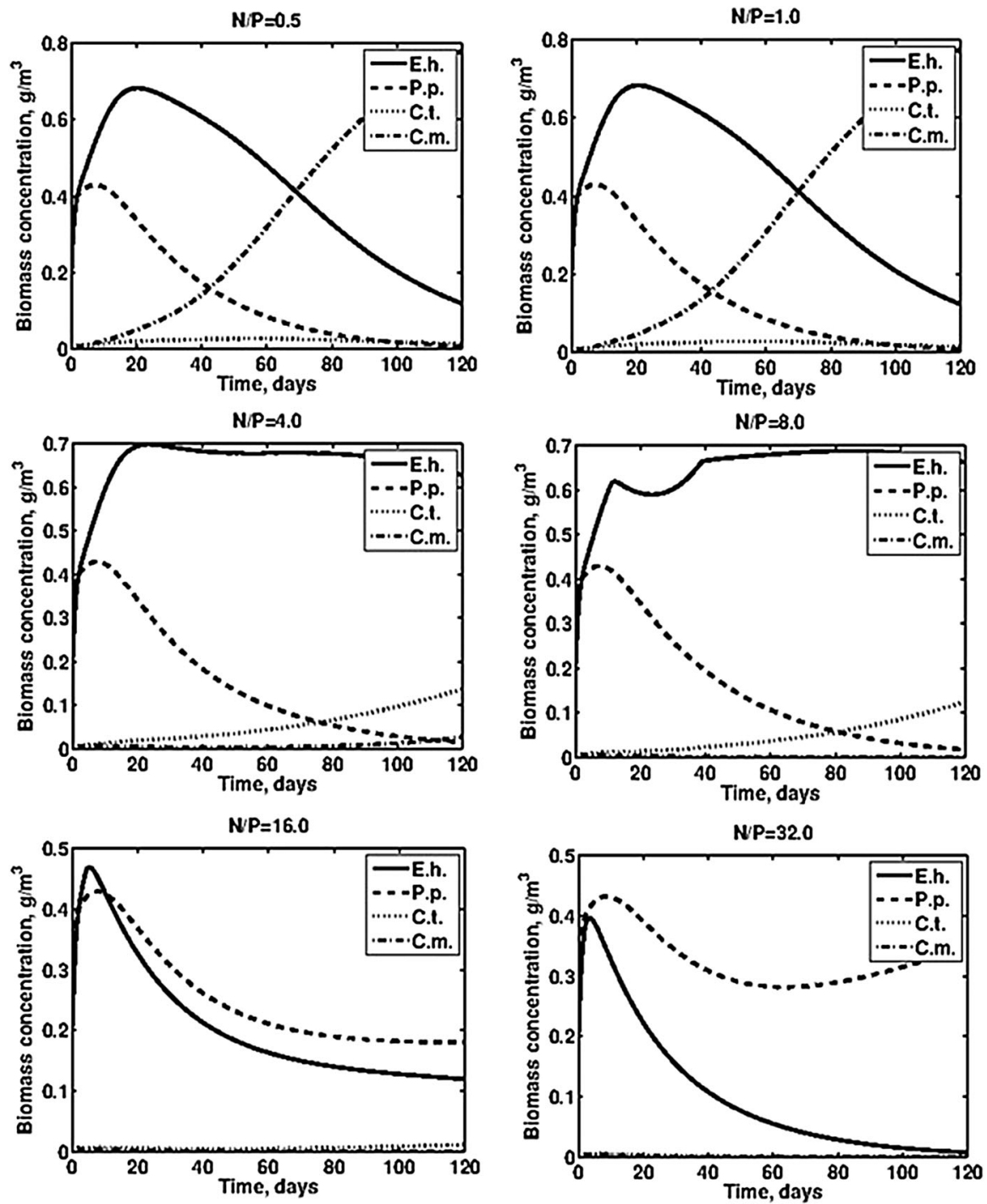

of phosphorus. Indeed, this species was observed in areas of increased eutrophication (Marino et al. 1991; Shevchenko et al. 2006; Genitsaris et al. 2011).

The invasive species $C$. throndsenii and the native species E. huxleyi can successfully coexist in the north-eastern part of the Black Sea. This indicates that the two species did not have a competition for one limiting factor. At this time, diatoms were represented by only this invasive species. This situation continued in June, indicating the prolonged preservation of a two-species community. The reasons for this phenomenon are apparent from the results of the experimental studies and mathematical modelling. Indeed, our experiments have shown that the successful development of this invasive species requires relatively higher concentrations of nitrogen and phosphorus. Unlike E. huxleyi, which requires for its growth increased concentrations of phosphorus, the diatom is more sensitive to nitrogen (Silkin et al. 2014). All of these suggest that this pair of species has two different limiting nutrients: the diatoms $C$. throndsenii are limited by the concentration of nitrogen and E. huxleyi by the phosphorus concentration. A community of two species having different limiting factors must be sustainable. Perennial theoretical and practical research on microbial communities, as well as on phytoplankton, has demonstrated the validity of this position (Tilman 1977; Abrosov and Bogolyubov 


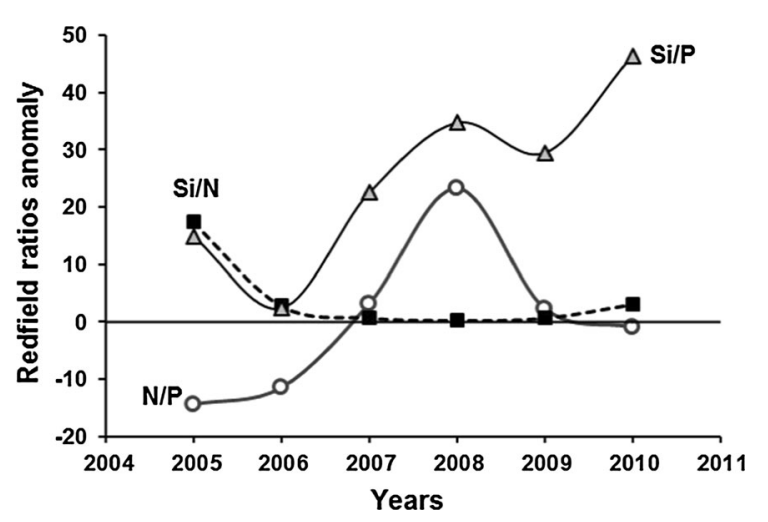

Fig. 6 Dynamics of relations between the basic nutrients in the upper $5 \mathrm{~m}$ layer on the shelf of the north-eastern part of the Black Sea in the period May-June (near Gelendzhik). The zero value corresponds to the theoretical Redfield ratio of nutrient (according to Brzezinski 1985)

1988; Silkin and Khailov 1988). Consequently, the pair "E. huxleyi and invasive species C. throndsenii", having different limiting factors, should have different half-saturation constants for nitrogen and phosphorus. The half-saturation constant of E. huxleyi for the nitrogen uptake rate must be less than this parameter of the invasive species. In turn, the half-saturation constant for the phosphorus uptake rate should be greater than that measured in C. throndsenii. Only then can these species coexist in steady-state conditions for an arbitrarily long period.

Evaluation of the kinetic parameters of the model based on the experimental data (Table 5) confirmed this position. Computational experiments on the model using data from the kinetic constants showed that the coexistence of these species depends on the ratio of nitrogen-to-phosphorus concentrations (Figs. 4 and 5). When the N:P ratio is in the range from 4 to 8 , such coexistence is possible. When $\mathrm{N}: \mathrm{P}$ is equal to 8,16 and 32 , the native species benefits in the competition and remains the dominant species.

However, there are conditions under which another invasive species, $C$. minimus, can gain a foothold in the ecosystem and even become dominant. This occurs when an increasing of the phosphorus concentration reduces the nitrogen-to-phosphorus ratio. C. minimus can become dominant when $\mathrm{N}: \mathrm{P}$ is below 1 , although this requires stable conditions for at least 2 months. In the natural condition, this is virtually impossible, because increase in the concentration of phosphorus is a rather episodic phenomenon (and local rather than widespread). Reducing the phosphorus concentration by its uptake by $C$. minimus and $E$. huxleyi leads to conditions under which the latter receives a competitive advantage. This pair does not form a community with different limiting factors, and therefore their joint coexistence would be impossible. This was also observed in nature when invasive species were recorded mainly in the coastal waters, where a local increase in the concentration of phosphorus was most likely to be found. In the open part of the sea, the growth of $C$. minimus was limited.

Hydrochemical data of the seawater during $E$. huxleyi intensive growth (Fig. 3) and the concomitant growth of invasive species are not inconsistent with the mentioned above propositions. Indeed, the nitrogen-to-phosphorus ratio during the intensive growth of the invasive species $C$. throndsenii was close to 1 . By mid-June 2005, a community of the invasive species and E. huxleyi was located on almost the entire explored area, and this community was close to steady state. At the end of May 2006, during an intense growth of coccolithophores, high concentrations of nitrogen and phosphorus were observed in the environment. This indicated that the community was far from steady state but it was in a transient state. At this time, high concentrations of phosphorus allowed invasive species $C$. minimus to grow in the ecosystem. The residual concentration of the limiting growth nutrient was determined primarily by the half-saturation constant for the uptake of this nutrient (Litchman et al. 2004). The coccolithophore E. huxleyi eventually became the dominant species, and the residual concentration of the limiting nutrient is determined by this species. Until the end of May, this species not yet become an absolute dominant. The ratio of nitrogen to phosphorous was equal to 7 , but with time the intensive growth of E. huxleyi decreased the concentration of both nitrogen and phosphorus and ratio of these nutrients. After 2006 the N:P ratio was not high (Fig. 6) and such conditions was not conducive to the growth of these invasive species.

Why are these species not recorded in the western part of the Black Sea? This part of the sea exposed to eutrophication and the species of spring complex there develop in the period of intensive growth coccolithophorids in the eastern part of the sea (Moncheva et al. 1995, 2001). During this period, the conditions for the existence of a pair of "E. huxleyi-C. throndsenii" are absent. The nutritional stoichiometry is not 
appropriate for intensive growth to another species $C$. minimus because there is a high concentration of nitrogen, and this leads to high values of the nitrogento-phosphorus ratio (Pakhomova et al. 2014).

With regard to the pathways of species invasion, the hypothesis of penetration of invasive species $C$. throndsenii via elevated intrusions of Mediterranean waters through the Bosphorus because the massive growth of this species was observed across the waters of the north-eastern part of the Black Sea. As for $C$. minimus, identifying the most preferred hypothesis of the penetration is not yet possible. This species has a high growth rate in high phosphorus concentration, and its cells have high rate of degradation under adverse conditions. Perhaps, C. minimus permanently or for a short time grow in the bays, but for various reasons it was not recorded earlier. In this case, this species is not an invasive species. Only recently on the scale of geological time (about 9000 years ago), the seawater began to arrive in the Black Sea (Ryan 2007). The formation of the Black Sea as a marine ecosystem took about 4000 years. Have the phytoplankton been stable in the ecosystem? One of the criteria of stability is resistance to invasion. Our research on the invasive diatoms C. throndsenii and C. minimus in 2005-2006 indicates that phytoplankton have some resistance. New species may appear in the phytoplankton, but to keep them in the ecosystem is required constancy of environmental conditions for a long time. The structure of the phytoplankton community has seasonal changes in response to changing environmental conditions. A certain set of species for every season is selected in the course of the evolution of the Black Sea ecosystem. Thus, it is difficult for new species to be fixed in the ecosystem, and only critical violations connected with climate changes or anthropogenic influences can lead to essential change of structure of a phytoplankton due to the emergence of new species.

Acknowledgments This work was funded by the Russian Foundation for Basic Research (grants 16-05-00268).

\section{References}

Abrosov NS, Bogolyubov AG (1988) Ecological and genetic regularities of existence and co-evolution of species (Ekologicheskie i geneticheskie zakonomernosti sosushchestvovaniya i koevolyutsii vidov ). Nauka, Novosibirsk (in Russian)
AlgaeBase database. (http://www.algaebase.org). Accessed 20 May 2014

Bordovskiy OK, Chernyakova AM (eds) (1992) Modern methods of the ocean hydrochemical investigations. PP Shirshov Institute of Oceanology, Moscow (in Russian)

Brzezinski M (1985) The Si:C: N ratio of marine diatoms: interspecific variability and the effect of some environmental variables. J Phycol 21:347-357

Droop MR (1974) The nutrient status of algal cells in continuous culture. J Mar Biol Assoc UK 54:825-855

Genitsaris S, Moustaka-Gouni M, Kormas KA (2011) Airborne microeukaryote colonists in experimental water containers: diversity, succession, life histories and established food webs. Aquat Microb Ecol 62(Suppl.):139-152

Gomez F (2008) Phytoplankton invasions: comments on the validity of categorizing the non-indigenous dinoflagellates and diatoms in European Seas. Mar Pollut Bull 56:620-628

Grashoff K, Kremling K, Ehrhard M (1999) Methods of seawater analysis. Wiley, Weinheim

Hillebrand H, Durselen C, Kirschtel D, Pollingher U, Zohary T (1999) Biovolume calculation for pelagic and benthic microalgae. J Phycol 35:403-424

Kiselev IA (1969) Plankton of seas and continental basins (Plankton morey i continentalnyh vodoemov), vol 1. Nauka, Leningrad (in Russian)

Litchman E, Klausmeier CA, Bossard P (2004) Phytoplankton nutrient competition under dynamic light regimes. Limnol Oceanogr 49:1457-1462

Maksimov VN (1980) Multifactorial experiment in biology (Mnogofactornyi experiment v boilogii ). Nauka, Moscow, pp 164-190 (in Russian)

Marino D, Giuffé G, Montresor M, Zingone A (1991) An electron microscope investigation on Chaetoceros minimus (Levander) comb. nov. and new observations on Chaetoceros throndsenii (Marino, Montresor and Zingone) comb. nov. Diatom Res 6:317-326

Mehnert G, Leunert F, Cires S, Johnk KD, Erucker J, Nixdorf B, Wiedner C (2010) Competitiveness of invasive and native cyanobacteria from temperate freshwaters under various light and temperature conditions. J Plankton Res 32:1009-1021

Mikaelyan AS, Silkin VA, Pautova LA (2011) Coccolithophorids in the Black Sea: interannual and long-term changes. Oceanology 51:45-53

Moncheva S, Petrova-Karadjova V, Palasov A (1995) Harmful algal blooms along the Bulgarian Black Sea coast and possible patterns of fish and zoobenthic mortalities. In: Lassus P, Arzul G, Denn E, Gentien P (eds) Harmful marine algal blooms. Lavoisier Publ. Incorp, Paris, pp 193-198

Moncheva S, Gotsis-Skretas O, Pagou K, Krastev A (2001) Phytoplankton blooms in Black Sea and Mediterranean coastal ecosystems subjected to anthropogenic eutrophication: similarities and differences. Estuar Coast Shelf 53:281-295

Pakhomova S, Vinogradova E, Yakushev E, Zatsepin A, Shtereva G, Chasovnikov V, Podymov O (2014) Interannual variability of the Black Sea proper oxygen and nutrients regime: the role of climatic and anthropogenic forcing. Estuar Coast Shelf Sci 140:134-145 
Parmesan C (2006) Ecological and evolutionary responses to recent climate change. Annu Rev Ecol Evol Syst 37:637-669

Pautova LA, Mikaelyan AS, Silkin VA (2007) The structure of the plankton community in shelf waters of the north-eastern part of the Black Sea in the period of mass bloom of Emiliania huxleyi in 2002-2005. Oceanology 47:408-417

Pautova LA, Silkin VA, Mikaelyan AS, Lukashova TA (2011) The growth of new species in the Black Sea: Chaetoceros throndsenii (Marino, Montresor \& Zingone) Marino, Montresor \& Zingone in natural and experimental conditions. Int J Algae 13:1-15

Pautova LA, Silkin VA, Lifanchuk AV (2013) New for the Black Sea species Chaetoceros minimus (Bacillariophyta): field observations and experimental studies. Int J Algae 15:121-134

Ryan WBF (2007) Status of the black sea flood hypothesis. In: Yanko-Hombach V, Gilbert AS, Panin N, Dolukhanov PM (eds) The Black Sea flood question: changes in coastline, climate and human settlement. Springer, Dordrecht, pp 63-88

Shevchenko OG, Orlova TY, Hernandez-Becerril DU (2006) The genus Chaetoceros (Bacillariophyta) from Peter the Great Bay, Sea of Japan. Bot Mar 4:236-258

Silkin VA, Khailov KM (1988) Bioecological mechanisms of aquaculture management. Nauka, Leningrad (in Russian)

Silkin VA, Pautova LA, Lifanchuk AV (2013) Physiological regulatory mechanisms of the marine phytoplankton community structure. Russ J Plant Physiol 60:541-548
Silkin VA, Pautova LA, Pakhomova SV, Lifanchuk AV, Yakushev EV, Chasovnikov VK (2014) Environmental control on phytoplankton community structure in the NE Black Sea. J Exp Marine Biol Ecol 461:267-274

The Black Sea Phytoplankton Check List. (http://www.phyto. bss.ibss.org.ua). Accessed 1 March 2014

Throndsen J, Hasle GR, Tangen K (2003) Norskkystplanktonflora. Almater Forlag AS, Oslo

Tilman D (1977) Resource competition between planktonic algae: an experimental and theoretical approach. Ecology 58:338-348

Tomas CR (ed) (1997) Identifying marine phytoplankton. Academic Press, San-Diego

Vinogradov ME, Sapojnikov VV, Shushkina EA (1992) Ecosystem of the Black Sea. Nauka, Moscow

Walther G, Roques A, Hulme PE, Sykes MT, Pyšek P, Kuhn I, Zobel M, Bacher S, Botta-Dukat Z, Bugmann H, Czucz B, Dauber J, Hickler T, Jarosk V, Kenis M, Klotz S, Minchin D, Moora M, Nentwig W, Ott J, Panov VE, Reineking B, Robinet C, Semenchenko V, Solarz W, Thuiller W, Vila M, Vohland K, Settele J (2009) Alien species in a warmer world: risks and opportunities. Trends Ecol Evol 24:686693

WoRMS (World Register of Marine Species). (http://www. marinespecies.org). Accessed 20 May 2014 